\title{
Protection of Rabbit Lungs from Endotoxin Injury by In Vivo Hyperexpression of the Prostaglandin G/H Synthase Gene
}

\author{
Jon T. Conary, Richard E. Parker, Brian W. Christman, Rhonda D. Faulks, Gayle A. King, \\ Barbara O. Meyrick, and Kenneth L. Brigham \\ Center for Lung Research, Vanderbilt University, Nashville, Tennessee 37232-2650
}

\begin{abstract}
A recombinant prostaglandin G/H (PGH) synthase gene has been expressed in vitro in bovine pulmonary artery endothelial cells and in vivo in rabbits by transfection with a plasmid using cationic liposomes. Transfection of bovine pulmonary artery endothelial cells with the PGH synthase cDNA resulted in increased intracellular PGH synthase protein (determined by Western blot analysis) and increased release of prostacyclin. Rabbits intravenously transfected with the PGH synthase gene had increased plasma levels of prostacyclin and $\mathrm{PGE}_{2}$, and their lungs produced increased amounts of the same eicosanoids. In an in situ, perfused preparation of PGH synthase transfected rabbit lungs, the pressor response to endotoxin was markedly attenuated. In addition, pulmonary edema and release of thromboxane $B_{2}$ into the perfusate after endotoxin infusion were markedly decreased in transfected lungs compared to controls (animals transfected with a pCMV4 construct that did not contain a cDNA insert). The data suggest that augmented endogenous production of prostacyclin and $\mathbf{P G E}_{2}$, achieved by liposome-mediated gene transfer, protects the lungs from endotoxin. This may be caused in part by suppression of endotoxin-stimulated thromboxane $B_{2}$ production. Modification of lipid mediator responses by in vivo transfection is a potential approach to the therapy of acute lung injury. (J. Clin. Invest. 1994. 93:1834-1840.) Key words: gene therapy $\bullet$ cyclooxygenase I • lipofection
\end{abstract}

\section{Introduction}

In vivo transfer of functioning genes into the lungs of animals has been accomplished for $\alpha-1$ antitrypsin, several reporter genes, and the cystic fibrosis transmembrane conductance regulator (1-7). In those studies, gene expression was demonstrated by immunohistochemical staining, reverse transcriptase PCR, or the presence of the reporter gene product, but alterations in organ function were not reported. Effective human gene therapy will require a sufficent level of gene expression to affect

Address correspondence to Jon T. Conary, Ph.D., Center for Lung Research, B-1 308 Medical Center North, Vanderbilt University, Nashville, TN 37232-2650.

Received for publication 7 June 1993 and in revised form 6 December 1993.

J. Clin. Invest.

(C) The American Society for Clinical Investigation, Inc.

$0021-9738 / 94 / 04 / 1834 / 07 \quad \$ 2.00$

Volume 93, April 1994, 1834-1840 physiological responses. We recently reported in vivo transgene expression by cationic liposome mediated delivery of DNA to the lungs by intravenous and aerosol routes $(1-3,7)$. In the present report, we demonstrate successful intravenous delivery of the prostaglandin $\mathrm{G} / \mathrm{H}(\mathrm{PGH})^{1}$ synthase gene, consequent increases in the lipid mediator products of this enzyme, and striking protection of the lung from the effects of exposure to endotoxin.

PGH synthase catalyzes the conversion of arachidonic acid to prostaglandin endoperoxides, precursors to biologically active compounds including thromboxanes, prostacyclin, $\mathrm{PGE}_{2}$ and other eicosanoids. PGH synthase is the rate limiting step in the cyclooxygenase pathway of arachidonic acid metabolism $(8,9)$. Prostacyclin and $\mathrm{PGE}_{2}$ are the principal eicosanoids generated by endothelial cells, and there is evidence that exogenous delivery of $\mathrm{PGE}_{2}$ can protect the lungs from endotoxin (10). Since even a small increase in the expression of PGH synthase, a catalytically active enzyme, could result in a marked increase in the local synthesis of prostaglandins, we reasoned that this approach might result in physiologic effects with less in vivo transgene expression than would otherwise be required.

In the present paper, we demonstrate that transfection of bovine pulmonary artery endothelial cells (BPAEC) with the cDNA coding for ovine PGH synthase results in an increase in both prostacyclin release and intracellular PGH synthase protein. In vivo delivery of this cDNA to rabbits yields increased lung generation of $\mathrm{PGE}_{2}$ and prostacyclin metabolite. In vivo transfection of rabbits with the ovine PGH synthase gene markedly reduces endotoxin stimulated pulmonary hypertension, pulmonary edema, and thromboxane $B_{2}$ release. Application of the techniques of gene transfer to the therapy of acute lung injury may prove feasible.

\section{Methods}

Plasmid construction. An ovine PGH synthase plasmid (pCMV4PGH) was constructed in the pCMV4 expression vector (a generous gift from Dr. Mark Magnuson, Vanderbilt University) using linker-primer polymerase chain reaction and a proofreading, high temperature DNA polymerase (Vent DNA polymerase; New England Biolabs, Beverly, MA) $(11,12)$. This construct uses the promoter region of the cytomegalovirus major immediate early gene to drive the expression of ovine PGH synthase. The pCMV4-PGH plasmid was propagated in Escherichia coli and purified using standard procedures (13).

1. Abbreviations used in this paper: BPAEC, bovine pulmonary artery endothelial cells; $\mathrm{PGH}$, prostaglandin $\mathrm{G} / \mathrm{H}$. 
Expression of $P G H$ synthase in vitro. BPAEC were grown to confluence in $100-\mathrm{mm}$ petri plates in DME and $10 \%$ FCS plus penicillin and streptomycin. At the time of transfection, the medium was replaced with DME without FCS. $15 \mu \mathrm{g}$ of plasmid DNA were combined with $45 \mu \mathrm{g}$ of Lipofectin ${ }^{\mathrm{TM}}$ reagent (Gibco-Bethesda Research Laboratories, Gaithersburg, MD) and added to the medium for $12 \mathrm{~h}$. At the end of the 12-h period, serum-free medium was removed and DME $+10 \%$ FCS was added.

PGH synthase protein analysis. BPAEC from transfection experiments were harvested 24,48 , and $72 \mathrm{~h}$ after transfection by scraping in phosphate-buffered saline and collected by centrifugation $(500 \mathrm{~g}, 10$ min). The cell pellet was lysed by sonication in the presence of $0.1 \%$ Triton X-100 (Sigma Immunochemicals, St. Louis, MO), and protein was determined by the Coomassie blue method of Read and Northcote (14). An aliquot $(100 \mu \mathrm{g})$ of each protein sample was subjected to PAGE under denaturing conditions using standard methods(15). After electrophoresis, the protein was electrically transferred to a sheet of nitrocellulose in a Transblot chamber (Bio-Rad Laboratories, Melville, NY).

Immunodetection of $\mathrm{PGH}$ synthase was performed using published methods (16). The initial antisera was a rabbit antisheep PGH synthase (PG120; Oxford Biologicals, Oxford, MI), which cross-reacts with PGH synthase from a number of species including rabbit, and the second antiserum was goat antirabbit IgG with an alkaline phosphataseconjugated group (The Binding Site, San Diego, CA). The substrate cleaved by the alkaline phosphatase was 5-bromo-4-indoyl phosphate, which yielded a chromogenic product in the presence of nitroblue tetrazolium. Laser densitometry was performed (Ultrascan Laser Densitometer; LKB Instruments Inc., Bromma, Sweden), and the resulting data were analyzed using the gel scan software package (LKB-Pharmacia, Inc., Piscataway, NJ).

Eicosanoid analysis. Samples of perfusate were purified by solidphase extraction and then assayed for 6-keto- $\mathrm{PGF}_{1 \alpha}$ (the stable metabolite of prostacyclin), $\mathrm{PGE}_{2}$, and thromboxane $\mathrm{B}_{2}$ using a competitive enzyme-linked immunoassay (17). This assay also was used to measure eicosanoids in supernatants from organ cultures and from cell cultures. Urine was obtained from control and experimental rabbits by bladder aspiration at the time of surgery and analyzed for 2,3-dinor-6-keto$\mathrm{PGF}_{1 \alpha}$ by stable isotope dilution methods in conjunction with gas chromatography/mass spectrometry using previously reported methods (18).

In situ hybridization. Tissue in situ hybridization was performed as previously described (19-21). Immediately upon death, the lungs were removed and placed in freshly prepared $4 \%$ paraformaldehyde in PBS ( $10 \mathrm{mM}$ potassium phosphate, $150 \mathrm{mM} \mathrm{NaCl}, \mathrm{pH} \mathrm{7.4)}$ at $4^{\circ} \mathrm{C}$ for $12-$ $24 \mathrm{~h}$. The vasculature was flushed with PBS and the lungs were fixed at a constant pressure of $35 \mathrm{~cm}$ of $\mathrm{H}_{2} \mathrm{O}$. The tissue were then dehydrated through graded $(30,50,70$, and $90 \%)$ ethanol and xylene, and embedded in paraffin wax. 5- $\mu \mathrm{m}$ thick sections were cut, floated on diethyl pyrocarbonate treated water, mounted on acid-washed, poly L-lysine coated glass slides and dried for $2 \mathrm{~h}$ at $55^{\circ} \mathrm{C}$. Sections were brought to PBS and treated with $1 \mu \mathrm{g} / \mathrm{ml}$ nuclease free proteinase K (Sigma Immunochemicals) for $15 \mathrm{~min}$ at $37^{\circ} \mathrm{C}$ followed by treatment with $0.1 \mathrm{M}$

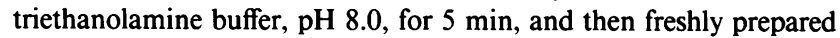
triethanolamine buffer containing $0.25 \%$ acetic anhydride. Slides were then washed twice in $2 \times \operatorname{SSC}(5 \mathrm{~min}$ in each) and dehydrated through graded alcohols and air dried.

Slides were hybridized with a single-stranded sense and antisense RNA probe as described below. The antisense probe was generated by digesting pCMV4-PGH plasmid with the restriction endonuclease $\mathrm{Kpnl}$ and performing a PCR reaction using a single primer complementary to bases $1683-1703$ (PGH) and including [ $\left.{ }^{33} \mathrm{P}\right] \mathrm{dATP}$ in the reaction mixture. A sense probe was made as described above using the restriction endonuclease $\mathrm{XbaI}$ and a primer identical to $\mathrm{PGH}$ synthase bases 1-20. The single-stranded PCR product was purified by chromatography through a Sephadex G-50 spin column. Hybridization was accomplished by applying $25 \mu$ l of hybridization buffer containing $50 \%$ formamide, $2 \times$ SSC, $20 \mathrm{mM}$ Tris, pH 8.0, $1 \times$ Denhardt's solution, 1 mM EDTA, $10 \%$ dextran sulfate, $100 \mathrm{mM}$ dithiothreitol, $0.5 \mathrm{mg} / \mathrm{ml}$ yeast transfer RNA, and $2.5 \times 10^{4} \mathrm{cpm}^{33} \mathrm{P}$-labeled RNA probe to the dry section and incubating overnight at $55^{\circ} \mathrm{C}$. Coverslips were placed over the sections during each hybridization step.

After incubation, the coverslips were removed and the slides were washed twice in $2 \times$ SSC containing $25 \mathrm{mM} \beta$-mercaptoethanol at room temperature. These sections were then washed at room temperature for $5 \mathrm{~min}$ in $0.5 \times$ SSC followed by a further wash in $0.1 \times$ SSC containing $\beta$-mercaptoethanol at $60^{\circ} \mathrm{C}$. Next, the sections were washed in $0.5 \mathrm{M} \mathrm{NaCl}, 10 \mathrm{mM}$ Tris $\mathrm{HCl}, 5 \mathrm{mM}$ EDTA (TEN buffer) at $37^{\circ} \mathrm{C}$. The sections were then washed twice in $2 \times$ SSC for $15 \mathrm{~min}$ at room temperature and then in $0.1 \times \mathrm{SSC}$ for $15 \mathrm{~min}$ at $65^{\circ} \mathrm{C}$ followed by a room temperature wash.

Sections were treated in 50\% Ilford L5 emulsion (Polysciences, Inc., Warrington, PA), dried and left to expose at $4^{\circ} \mathrm{C}$ for $7 \mathrm{~d}$. The slides were developed in Kodak D-19, fixed, washed, dried, and counterstained in Harris hematoxylin.

The procedure for in situ hybridization of BPAEC was similar to that of tissue. BPAEC were grown on coverslips and transfected with either pCMV4 or pCMV4-PGH, or treated with Lipofectin ${ }^{\mathrm{TM}}$. After fixation (paraformaldehyde, $4^{\circ} \mathrm{C}, 15 \mathrm{~min}$ ) the coverslips were left overnight at $4^{\circ} \mathrm{C}$ in $70 \%$ ethanol/diethylpyrocarbonate-treated water. The coverslips were then refixed for $15 \mathrm{~min}$ at $4^{\circ} \mathrm{C}$, washed in PBS, and then processed as described for tissue sections beginning with the proteinase $\mathrm{K}$ treatment.

Expression of PGH synthase in vivo. Purified plasmid $(800 \mu \mathrm{g})$ was combined with $2.5 \mathrm{mg}$ of Lipofectin ${ }^{\mathrm{TM}}$ and injected into the marginal ear vein of New Zealand white rabbits ( $5 \mathrm{ml}$ total volume). $1 \mathrm{~d}(24 \mathrm{~h}$ ) after transfection, blood samples were obtained and the animals were killed with an overdose of thiopental administered intravenously. The lungs were removed and either fixed for in situ hybridization (see above) or 1-g samples were obtained for organ culture. Organ cultures were established in DME supplemented with $10 \%$ FCS and antibiotics (penicillin and streptomycin), and $\mathrm{PGE}_{2}$ and prostacyclin levels were measured in the medium after $24 \mathrm{~h}$ incubation at $37^{\circ} \mathrm{C}$ in a $95 \% \mathrm{O}_{2}$ and $5 \% \mathrm{CO}_{2}$ atmosphere. Control rabbits were treated identically, except that they were transfected with a pCMV4 plasmid that did not contain the PGH synthase coding sequence.

$R N A$ analysis. $24 \mathrm{~h}$ after transfection with either empty pCMV4 or pCMV4-PGH synthase by the protocol described above, animals were given an overdose of thiopental sodium. The lungs, liver, and kidneys were removed, $1 \mathrm{~g}$ of each tissue was homogenized in guanidinium isothiocyanate, and total RNA was isolated as previously described (22). The quality of the RNA was determined by electrophoresis in a $1.2 \%$ agarose denaturing gel. After electrophoresis of $20 \mu \mathrm{g}$ of total RNA from all three organs on a $1.2 \%$ agarose denaturing gel, the RNA was transferred by capillary action to a nylon membrane (Amersham Corp., Arlington Heights, IL). Northern analysis was performed on the transferred RNA using ovine PGH synthase cDNA as a probe and standard methods (23).

Reverse transcriptase PCR, a more sensitive method of RNA detection, was performed using $6 \mu \mathrm{g}$ of lung RNA from both control and experimental animals (24). The lung RNA was combined with a 20mer primer complementary to ovine PGH synthase mRNA between bases 1680 and 1700 , Tet $\mathrm{z}$ buffer, $200 \mu \mathrm{M}$ dNTP, and high temperature reverse transcriptase ( $5 \mathrm{U}$ ) (Tet $\mathrm{z}$; Amersham Corp.) and incubated at $62^{\circ} \mathrm{C}$ for $15 \mathrm{~min}$. After first strand cDNA synthesis was complete, two primers, 328 bases apart at the $5^{\prime}$ end of PGH synthase cDNA, were added with $200 \mu \mathrm{M}$ dNTP and plaque-forming units DNA polymerase (1 U) (Stratagene, La Jolla, CA), and a polymerase chain reaction was performed for 35 cycles. The resultant bands were visualized by staining with ethidium bromide after electrophoresis through a $2 \%$ agarose gel. Ovine PGH synthase yields a 328-bp band.

In situ-perfused lung preparation. $24 \mathrm{~h}$ after transfection with either pCMV4-PGH or empty pCMV4 vector by the protocol described above, rabbits were weighed and restrained. 3-4 $\mathrm{ml}$ of an anesthetic solution, 1 part thiopental sodium $(16 \mathrm{mg} / \mathrm{ml})$ in 2 parts heparinized saline, were infused via a marginal ear vein. The animal was removed from the restraint and secured in the supine position. After a second 
bolus of anesthetic was administered, a tracheostomy was performed, and the animal was ventilated at a tidal volume of $30 \mathrm{ml}$ at a rate of 40 breaths per minute. A carotid artery was cannulated, and 3,000-4,000 $U$ of heparin were infused via the cannula. After $5 \mathrm{~min}$, the rabbit was rapidly exsanguinated, and the shed blood was used as perfusate, maintained at $38^{\circ} \mathrm{C}$.

A midline incision was made below the xiphoid process, and a parasternal incision was made to allow extirpation of the costal cartilages. The inferior vena cava, descending aorta, and esophagus were ligated and a urine sample was obtained for eicosanoid analysis by direct bladder puncture. The pericardium was opened, and the main pulmonary artery was ligated with a loosely tied suture. The heart was incised immediately proximal to the pulmonic valve, and the inflow cannula was tied in the main pulmonary artery. The apex of the heart was removed, and the outflow cannula was inserted through the mitral valve into the left atrium. The perfusion system was checked for air bubbles, the pulmonary artery ligature was removed, and pulmonary perfusion at $100 \mathrm{ml} / \mathrm{min}$ (hematocrit $25-28 \%$ ) and positive pressure ventilation $\left(3 \mathrm{ml} / \mathrm{kg}\right.$, rate 20 with $5 \% \mathrm{CO}_{2}$ in room air) were started. After $30 \mathrm{~min}$, to establish stable baseline values, a single bolus of LPS (4 $\mu \mathrm{g} / \mathrm{kg}$ original body wt) was added to the perfusate. Pulmonary arterial pressure was constantly monitored via transducer (Validyne Engineering Corp., Northridge, CA) and an electronic recorder (Hewlett-Packard Co., Palo Alto, CA). Aliquots of blood were withdrawn (and immediately combined with $50 \mu \mathrm{g}$ of indomethacin) at 10 -min intervals for measurements. The lungs were maintained with blood perfusion at constant flow $(100 \mathrm{ml} / \mathrm{min})$ and positive pressure ventilation during the entire experiment. As an additional measure of lung injury, a piece of rabbit lung was removed at the end of the in situ perfusion experiments, and the ratio of the weight of the tissue before and after desiccation (wet/dry ratio) was determined (25).

Statistics. Statistical evaluation of the data was performed using True Epistat, Ver. 4 (Epistat Services, Richardson, TX).

\section{Results}

Transfection of BPAEC in culture with the PGH synthase gene. BPAEC transfected with pCMV4-PGH synthase/liposome complex produced twofold increased amounts of 6-keto-PGF ${ }_{1 \alpha}$ $(10.5 \mathrm{ng} / 24 \mathrm{~h}$ per $100-\mathrm{mm}$ plate) compared to 5.8 for cells transfected with a PGH synthase-free plasmid. Fig. 1 shows the results of a Western analysis for ovine PGH synthase protein in transfected BPAEC. Fig. $1 A$ shows a PGH synthase protein standard, and Fig. $1 B$ shows the results from a BPAEC transfection experiment. These proteins have the same molecular weight and react with the same antiserum. Quantitation of the Western analysis by laser densitometry revealed that PGH synthase protein was increased threefold in cells transfected with ovine PGH synthase cDNA compared to empty vector-transfected control cells. Peak PGH synthase protein expression was observed in BPAEC harvested $24 \mathrm{~h}$ after transfection. In situ hybridization (Fig. 2, $A$ and $B$ ) shows that $\sim 20 \%$ of the BPAEC transcribes the PGH synthase transgene.

In vivo transfection of PGH synthase cDNA. Production of both $\mathrm{PGE}_{2}$ and prostacyclin was six- to eightfold higher in organ cultures of lung from rabbits transfected with PGH synthase than in empty vector-transfected controls (Fig. 3). In separate experiments, organ cultures were established in the presence of radiolabeled $\mathrm{PGE}_{2}$, and no differences in $\mathrm{PGE}_{2}$ half-life were observed (data not shown) between animals transfected with PGH synthase and empty vector-transfected controls. Plasma concentrations of 6-keto-PGF ${ }_{1 \alpha}$ were higher at baseline in rabbits transfected with the ovine gene (6-keto$\mathrm{PGF}_{1 \alpha}$ plasma concentration $152 \mathrm{pg} / \mathrm{ml}$ in PGH synthase transfected animals vs $<20 \mathrm{pg} / \mathrm{ml}$ in empty vector-transfected

\section{kD}
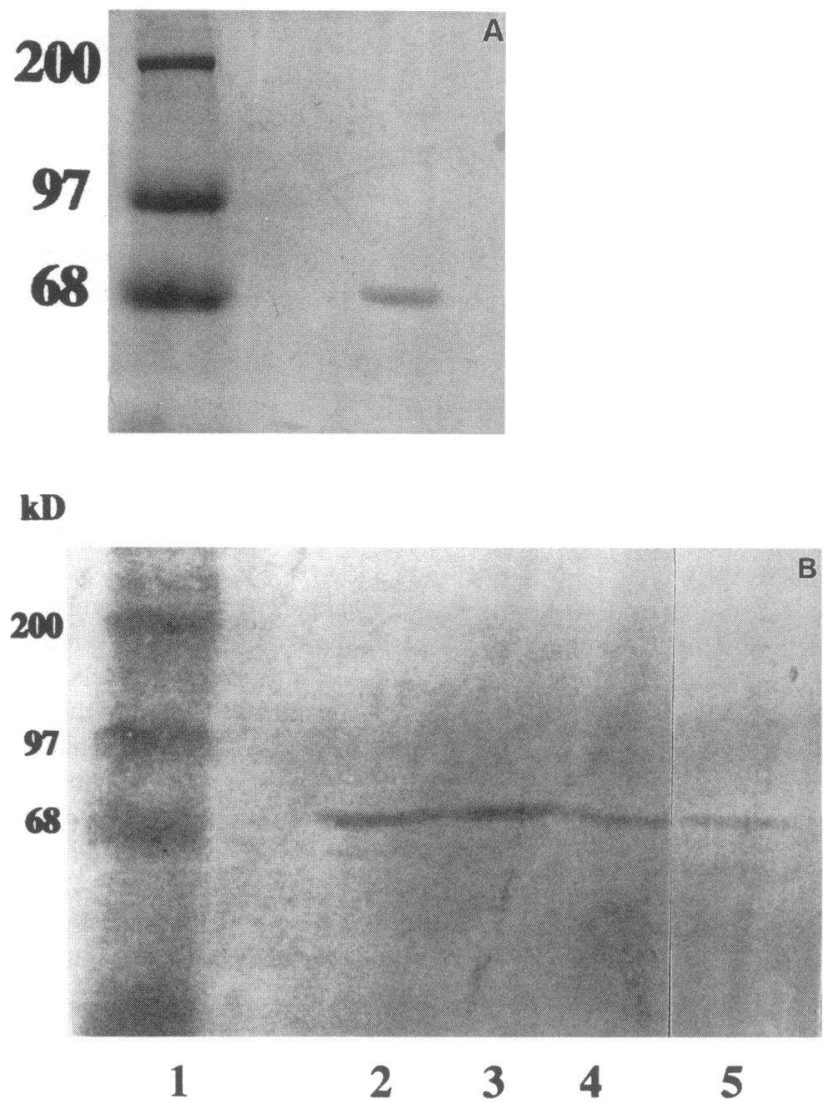

Figure 1. Western Blot analysis of PGH synthase $(A)$. Protein standards are shown in lane $l$ and PGH synthase standard is in lane 2. Western Blot analysis of ovine PGH synthase protein from transfected cells $(B)$. The cells transfected with PGH synthase were harvested 24, 48 , and $72 \mathrm{~h}$ after transfection, lanes $2-4$, respectively. The transfected cells produced greater amounts of this protein than did the empty vector-transfected control that was harvested at $24 \mathrm{~h}$ (lane 5). Protein standards are shown in lane 1 . One of three independent experiments with similar results is shown.

controls). In addition, 2,3-dinor-6-keto-PGF , $_{1 \alpha}$, the stable major urinary metabolite of prostacyclin, was present in higher amounts in urine obtained from animals transfected with the ovine PGH synthase gene $(10.30 \pm 1.10 \mathrm{ng} / \mathrm{mg}$ creatinine) than in empty vector-transfected animals $(5.69 \pm 0.53 \mathrm{ng} / \mathrm{mg}$ creatinine $[n=3, P<0.05])$ suggesting successful functioning of the PGH synthase cDNA.

PGH synthase mRNA was not detected by Northern blot analysis. This may reflect either the extremely transient nature of the PGH synthase message or indicate that a low percentage of cells was successfully transfected in vivo. mRNA for ovine PGH synthase was present in the lungs of transfected rabbits as shown by RT-PCR but was not detected in kidney or liver (Fig. 4). Successful in vivo transfection of ovine PGH synthase was demonstrated in rabbit lung by in situ hybridization. Sections of rabbit lung were probed with either an antisense probe (Fig. 5 ) or a sense probe (data not shown). Hybridization occurred only with the antisense probe, and the signal was found in the alveolar walls at a position consistent with an endothelial location. 

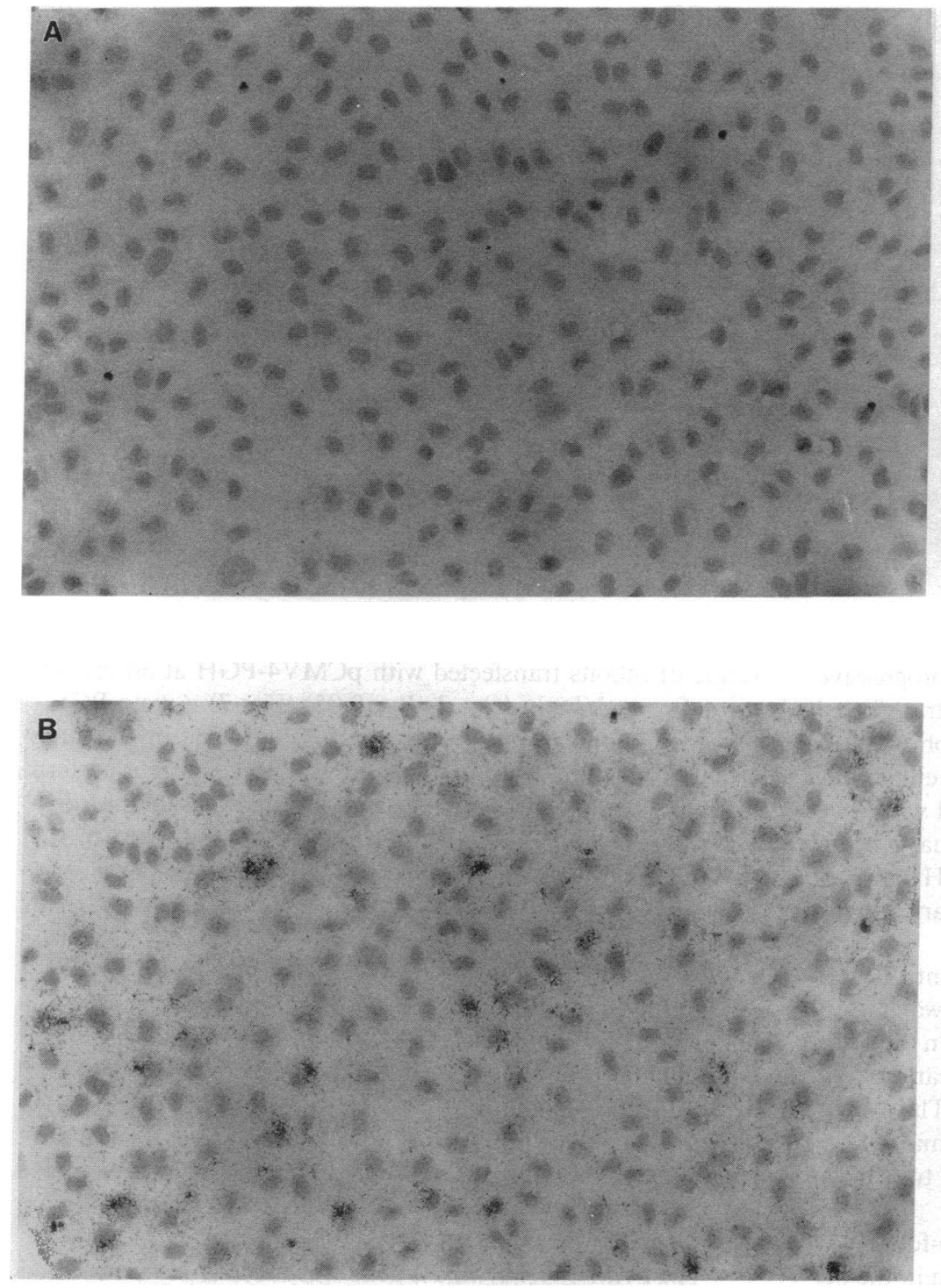

Figure 2. In situ hybridization of BPAEC transfected with pCMV4-PGH. $(A)$ Cells were probed with a sense probe (control) and $(B)$ an antisense probe for ovine PGH synthase. The signal with the antisense probe is striking: $\sim 20 \%$ of the cells are labeled.

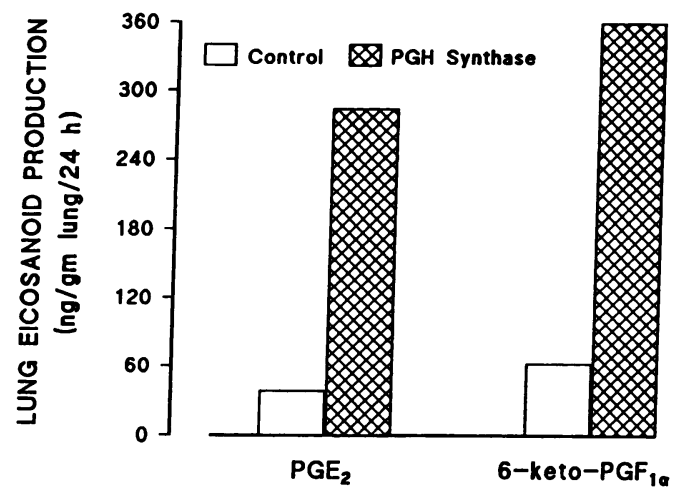

Figure 3. Rabbit lung eicosanoid production after transfection with PGH synthase cDNA. Organ cultures were established $24 \mathrm{~h}$ after transfection, and the concentration of $\mathrm{PGE}_{2}$ and prostacyclin in the medium was determined over a $24-\mathrm{h}$ period in culture. One of three experiments with similar results is shown.

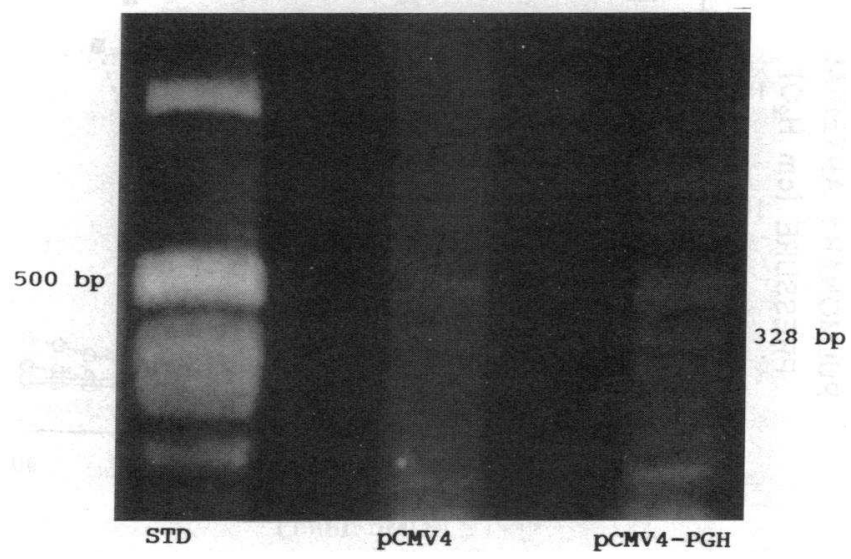

Figure 4. Reverse transcriptase polymerase chain reaction of pCMV4-PGH-transfected rabbit lung. The 328-bp band seen in lane 3 is the PGH synthase reverse transcriptase-PCR product. Lane 1 is a DNA size ladder and lane 2 shows the results of reverse transcriptase-PCR performed on a lung from an animal transfected with empty vector. 


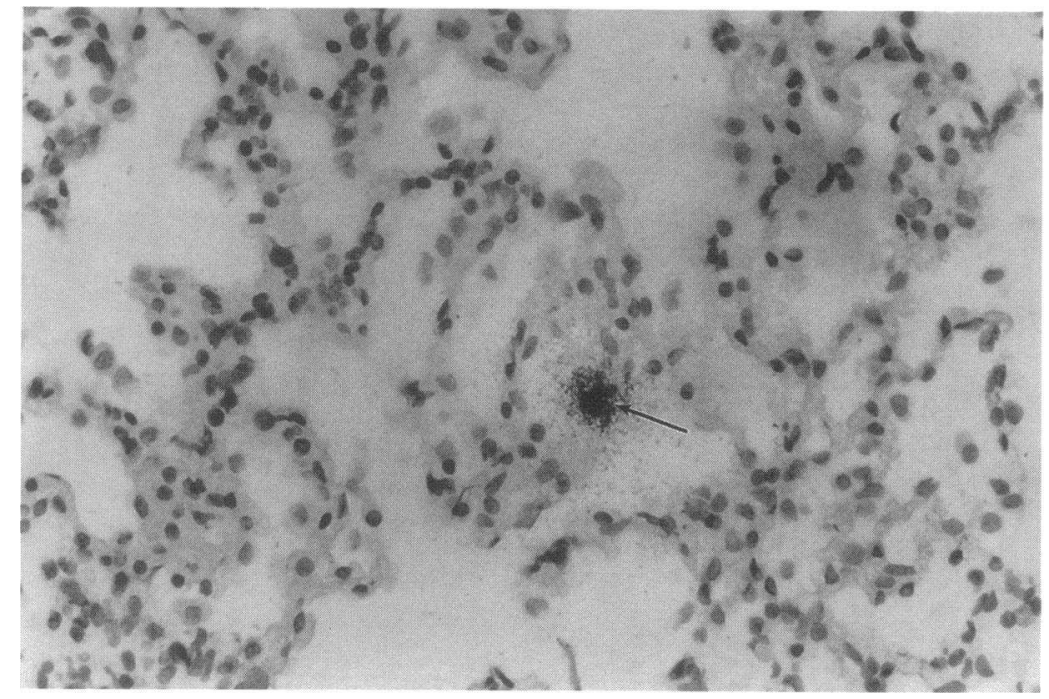

Figure 5. In situ hybridization in lung from a rabbit transfected with ovine PGH synthase probed with an antisense probe. The most prominent signal is seen in the alveolar region (arrow).
In situ lung studies. LPS caused a rapid and progressive increase in mean pulmonary artery pressure in nontransfected lungs (data not shown) and in the lungs of the rabbits transfected with empty pCMV4 vector (Fig. 6). Experiments in the empty vector-transfected controls were terminated within 90 min of endotoxin infusion because of severe pulmonary hypertension. Lungs of rabbits transfected with the PGH synthase gene showed only minimal increases in pulmonary arterial pressure after the administration of LPS.

The average pulmonary artery pressure in the control group at the 50 -min time point was $91.2 \pm 52.2 \mathrm{~cm}$ of water (four animals). The average pulmonary arterial pressure in the transfected rabbits at the 50-min time point was significantly lower at $18.3 \pm 2.2 \mathrm{~cm}$ of water (four animals) $(P<0.05)$. The average wet/dry weight ratio of the LPS-treated control animals $(n=3)$ was $8.4 \pm 1.8$, while the ratio in the PGH synthase transfected group $(n=4)$ was $4.79 \pm 0.3(P<0.05)$.

Perfusate thromboxane concentrations were 10 -fold higher in the empty vector-transfected control group than in the per-

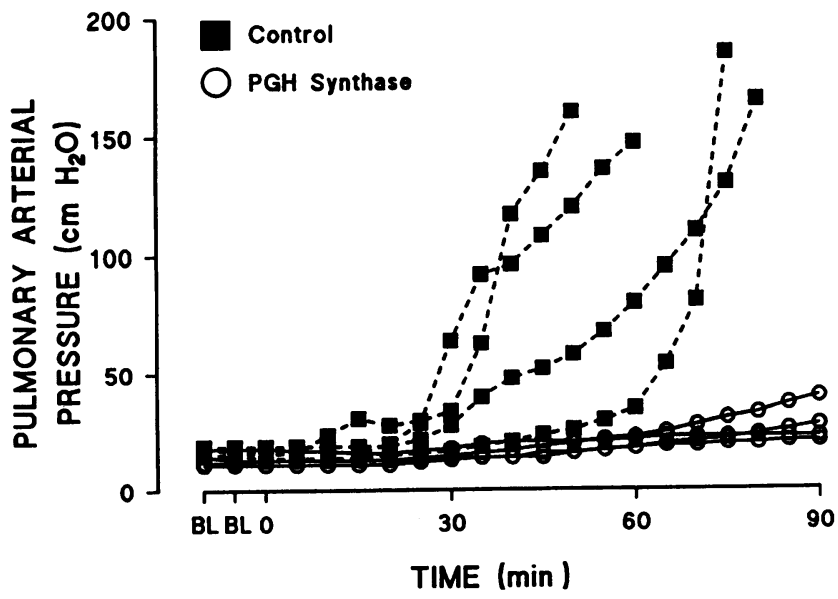

Figure 6. Rabbits were transfected with $800 \mu \mathrm{g}$ of either pCMV4 or pCMV4-PGH $24 \mathrm{~h}$ before establishing an in situ lung preparation. Pulmonary arterial pressure was monitored continuously during the experiment (each symbol represents one animal). Endotoxin $(4 \mu \mathrm{g} / \mathrm{kg})$ was added to the perfusate at time 0 . The values at $50 \mathrm{~min}$ were significantly different between the two groups $(P<0.05)$. fusate of rabbits transfected with pCMV4-PGH at 50 and 60 min after endotoxin $(n=3, P<0.05)$ (Fig. 7). 6-keto-PGF ${ }_{1 \alpha}$ and $\mathrm{PGE}_{2}$ concentration in the perfusate during in situ lung studies were highly variable and showed no consistent pattern in either empty vector-transfected controls or rabbits transfected with pCMV4-PGH, possibly as a consequence of the trauma of the preparation (26).

\section{Discussion}

We previously demonstrated successful transfection of BPAEC and of the lungs of intact animals with genes encoding chloramphenicol acetyltransferase, human growth hormone, and $\alpha-1$ antitrypsin (1-3). Because cyclooxygenase products of arachidonic acid are important in lung homeostasis and in inflammatory responses, we tested the feasibility and effects of transfection with PGH synthase, a key enzyme in prostaglandin synthesis.

The ovine PGH synthase gene was successfully transfected in BPAEC. This was demonstrated by increased release of the primary arachidonic acid metabolites from vascular endothe-

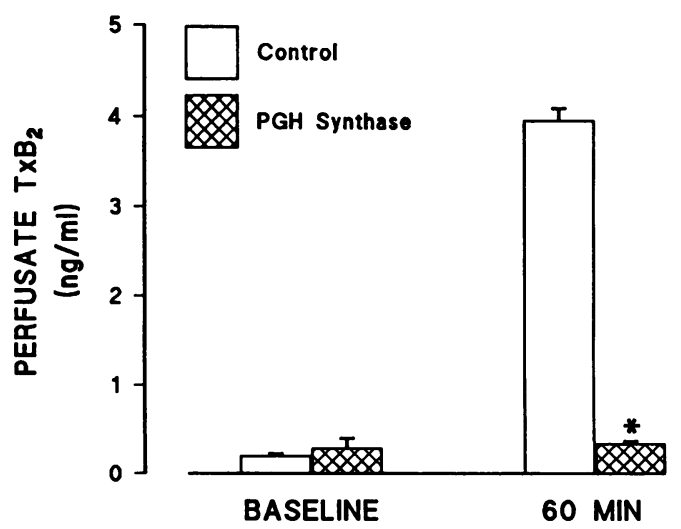

Figure 7. Thromboxane B2 concentrations in lung perfusate after LPS administration. Thromboxane was higher in the rabbits transfected with pCMV4 (open box) than in perfusate samples taken from the rabbits transfected with pCMV4-PGH (hatched box) at the 60-min time point. ${ }^{*}$ Values significantly different from LPS-treated controls $(P<0.05)$. 
lium, $\mathrm{PGE}_{2}$ and prostacyclin, increased levels of intracellular PGH synthase protein, and demonstration of transgene message by in situ hybridization.

Lungs removed from animals $24 \mathrm{~h}$ after intravenous transfection with the PGH synthase gene produced increased amounts of $\mathrm{PGE}_{2}$ and prostacyclin in organ cultures. Urine from PGH synthase-transfected animals contained increased amounts of prostacyclin metabolite. mRNA specific for the ovine PGH synthase transgene was found in the lungs of the transfected rabbits by reverse transcriptase-PCR, and transgene message was detected in the lung periphery by in situ hybridization.

These data demonstrate that cationic liposomes can deliver a functioning plasmid vector expressing the PGH synthase gene to lung endothelial cells in culture and to the lungs of intact animals. Expression of the PGH synthase gene sufficient to increase production of the endothelium-derived eicosanoids, prostacyclin and $\mathrm{PGE}_{2}$, can be achieved by this methodology both in cultured cells and in vivo.

In situ perfused lung studies were performed $24 \mathrm{~h}$ after transfection. This time point was selected because BPAEC harvested $24 \mathrm{~h}$ after transfection produced the greatest amount of immunoreactive PGH synthase. Transgene expression continues for a longer period, as we have shown increased prostacyclin in the medium from organ cultures that were established $48 \mathrm{~h}$ after the animal was transfected with the cDNA for ovine PGH synthase. In vivo transfection with a pCMV4 construct containing the cDNA coding for human $\alpha$-1-antitrypsin results in expression of $\alpha$-1-antitrypsin for $\geq 7 \mathrm{~d}(27)$.

Lipopolysaccharide(endotoxin) from Gram-negative bacteria causes many pathophysiologic alterations in the lung, including pulmonary hypertension and edema (28). Studies with cyclooxygenase inhibitors and thromboxane-endoperoxide antagonists suggest that much of the LPS induced increase in pulmonary arterial pressure is a consequence of increased production of thromboxane $A_{2}$ (29). In previous studies in chronically instrumented sheep, infusion of $\mathrm{PGE}_{2}$ attenuated LPS-induced pulmonary hypertension and decreased thromboxane generation (10). In the rabbit perfused lung model, the thromboxane receptor blocker SQ-29548 attenuates LPS-induced pulmonary hypertension (Parker, R. E., personal communication). Prostacyclin is a pulmonary vasodilator and through its antiplatelet effect, can inhibit thromboxane generation (30). Thus increased levels of $\mathrm{PGE}_{2}$ and prostacyclin might lower thromboxane $A_{2}$ to levels that could in turn result in an attenuation of pulmonary hypertension observed after LPS challenge.

We hypothesized that intravenous delivery of pCMV4 PGH might preferentially transfect pulmonary endothelium, resulting in increased generation of prostacyclin and $\mathrm{PGE}_{2}$ and attenuation of the LPS response. We recently demonstrated that plasmid DNA labeled with $\left[{ }^{33} \mathrm{P}\right] \mathrm{dCTP}$ combined with cationic liposomes and injected intravenously into rabbits localizes in the vascular endothelium of the lung (27). The in situ hybridization data reported here are consistent with localization of transgene expression in peripheral lung endothelium. Increased prostacyclin and $\mathrm{PGE}_{2}$ production in $\mathrm{PGH}$ synthase transfected animals is also consistent with endothelial expression of the transgene.

In an in situ lung preparation, we demonstrated marked attenuation of pulmonary hypertension and pulmonary edema in response to endotoxin in the lungs of animals transfected with the PGH synthase gene. We also showed that the perfusate from the rabbits transfected with pCMV4-PGH contained much less thromboxane after LPS challenge than in animals transfected identically with the empty vector.

We show that a recombinant gene can be expressed and have functional consequences in the lungs in vivo using a plasmid vector and liposome-mediated gene delivery. This method has the advantages of direct gene delivery to lung cells. The use of plasmids as the DNA source should minimize the risk of integration of the transfected gene into the host genome. These studies demonstrate that when a gene coding for a catalytically active enzyme is transfected, sufficient amounts of the reactive product(s) can be produced by the enzyme to significantly alter a physiological response even under circumstances where the amount of mRNA coding for the transfected gene may be low.

This approach to gene hyperexpression minimizes many of the potential complications of gene therapy and has potential to be useful in the treatment of both acquired and inherited diseases. Use of these methods in therapy of acute lung injury is especially attractive because there is no current therapy with proven efficacy, a single administration of plasmid would probably be sufficient and only transient expression of the foreign gene is needed.

\section{Acknowledgments}

This work was supported by funding from the National Institutes of Health grants HL-45151, HL-19153, HL-27274, and HL-07123, and a research grant from the American Lung Association (Dr. Conary). Dr. Brigham is the Joe and Morris Werthan Professor of Investigative Medicine.

The authors would like to thank Tamara Lasakow for her assistance in preparing the manuscript.

\section{References}

1. Canonico, A. E., J. T. Conary, B. W. Christman, B. O. Meyrick, and K. L. Brigham. 1991. Expression of a CMV promoter driven human $\alpha-1$ antitrypsin gene in cultured lung endothelial cells and in the lungs of rabbits. Clin. Res. 39:219A.

2. Brigham, K. L., B. Meyrick, B. Christman, M. Magnuson, G. King, and L. C. Berry, Jr. 1989. In vivo transfection of murine lungs with a functional prokaryotic gene using a liposome vehicle. Am. J. Med. Sci. 298:278-281.

3. Brigham, K. L., B. Meyrick, B. Christman, J. T. Conary, G. King, L. C. Berry, Jr., and M. A. Magnuson. 1993. Expression of human growth hormone fusion genes in cultured lung endothelial cells and in the lungs of mice. Am. J. Respir. Cell Mol. Biol. 8:209-213.

4. Stribling, R., E. Brunette, D. Liggitt, K. Gaensler, and R. Debs. 1992. Aerosol gene delivery in vivo. Proc. Nat. Acad. Sci. USA. 89:11277-11281.

5. Conary, J. T., A. E. Canonico, R. E. Parker, B. W. Christman, G. King, and K. L. Brigham. Expression of a CMV promoter driven ovine prostaglandin $\mathrm{G} / \mathrm{H}$ synthase gene in the lungs of rabbits. 1992. Am. Rev. Respir. Dis. 145:A850.

6. Nabel, E. G., G. Plautz, and G. J. Nabel. 1990. Site-specific gene expression in vivo by direct gene transfer into the arterial wall. Science (Wash. DC). 249:1285-1288.

7. Yoshimura, K., M. A. Rosenfeld, H. Nakamura, E. S. Schrer, A. Pavirani, J. P. Lecocq, and R. G. Crystal. 1992. Expression of the human cystic fibrosis transmembrane conductance regulator gene in the mouse lung after in vivo intratracheal plasmid-mediated gene transfer. Nucleic Acids Res. 20:3233-3240.

8. DeWitt, D. L. 1991. Prostaglandin endoperoxide synthase: regulation of enzyme expression. Biochem. Biophys. Acta. 1083:121-134.

9. Merlie, J. P., D. Fagan, J. Mudd, and P. Needleman. 1988. Isolation and characterization of the complementary DNA for sheep seminal vesicle prostaglandin endoperoxide synthase (cyclooxygenase). J. Biol. Chem. 263:3550-3553.

10. Brigham, K. L., W. Serafin, A. Zadoff, I. Blair, B. Meyrick, and J. A. Oates. 1988. Prostaglandin $E_{2}$ attenuation of sheep lung responses to endotoxin. J. Appl. Physiol. 64:2568-2574.

11. Andersson, S., D. L. Davis, H. Dahlback, H. Jornvall, and D. W. Russell. 1989. Cloning, structure, and expression of the mitochondrial cytochrome P-450 sterol 26-hydrolase, a bile acid biosynthetic enzyme. J. Biol. Chem. 264:82228229 . 
12. Coen, D. M. 1993. Enzymatic amplification of DNA by PCR: standard procedures and optimization. In Current Protocols in Molecular Biology. F. M. Ausbel, R. Brent, R. E. Kingston, D. D. Moore, J. G. Seidman, J. A. Smith, and K. Struhl, editors. Greene Publishing and Wiley-Interscience, New York. pp. 15.1.1-15.1.7.

13. Heilig, J. S., K. Lech, and R. Brent. 1993. Large scale preparation of plasmid DNA. In Current Protocols in Molecular Biology. F. M. Ausubel, R. Brent, R. E. Kingston, D. D. Moore, J. G. Seidman, J. A. Smith, and K. Struhl, editors. Greene Publishing and Wiley-Interscience, New York. pp. 1.7.1-1.7.11.

14. Read, S. M., and D. H. Northcote. 1981. Minimization of variation in the response to different proteins of the Coomassie blue $G$ dye-binding assay for protein. Anal. Biochem. 116:53-64.

15. Gallagher, S., and J. A. Smith. 1993. Electrophoretic separation of proteins. In Current Protocols in Molecular Biology. F. M. Ausubel, R. Brent, R. E. Kingston, D. D. Moore, J. G. Seidman, J. A. Smith, and K. Struhl, editors. Greene Publishing and Wiley-Interscience, New York. pp. 10.2.1-10.2.21.

16. Gallagher, S., S. E. Winston, S. A. Fuller, and J. G. R. Hurrell. 1993. Immunoblotting and Immunodetection. In Current Protocols in Molecular Biology. F. M. Ausubel, R. Brent, R. E. Kingston, D. D. Moore, J. G. Seidman, J. A. Smith, and K. Struhl, editors. Greene Publishing and Wiley-Interscience, New York. pp. 10.8.1-10.8.16

17. Westcott, J. Y., S. Chang, M. Balazy, D. O. Stene, P. Pradelles, J. Maclouf, N. F. Voelkel, and R. C. Murphy. 1986. Analysis of 6-keto PGF la, $5-H E T E$ and $\mathrm{LTC}_{4}$ in rat lung: comparison of GC/MS, RIA, and EIA. Prostaglandins. 32:857873.

18. Fitzgerald, G. A., B. Smith, A. K. Pedersen, and A. R. Brash. 1984. Increased prostacyclin biosynthesis in patients with severe atherosclerosis and platelet activation. N. Engl. J. Med. 310:1065-1068.

19. Prosser, I. W., K. R. Stenmark, M. Suthar, E. C. Crouch, R. P. Mecham, and W. C. Parks. 1989. Regional heterogeneity of elastin and collagen gene expression in intralobar arteries in response to hypoxic pulmonary hypertension by in situ hybridization. Am. J. Pathol. 135:1073-1088.

20. Quaglino, D., L. B. Nanney, R. Kennedy, and J. M. Davidson. 1990.
Transforming growth factor- $\beta$ stimulates wound healing and modulates extracellular matrix gene expression in pig skin. Lab. Invest. 63:307-319.

21. Pelton, R. W., S. Nomura, H. L. Moses, and B. L. M. Hogan. 1989. Expression of transforming growth factor (TGF)- $\beta 2$ RNA during murine embryogenesis. Development (Camb.). 106:759-767.

22. Chomczynski, P., and N. Sacchi. 1987. Single-step method of RNA isolation by acid guanidinium thiocyanate-phenol-chloroform extraction. Anal. Biochem. 162:156-159.

23. Brown, T. 1993. Analysis of RNA by northern and slot blot hybridization. In Current Protocols in Molecular Biology. F. M. Ausubel, R. Brent, R. E. King ston, D. D. Moore, J. G. Seidman, J. A. Smith, and K. Struhl, editors. Greene Publishing and Wiley-Interscience, New York. pp. 4.9.1-4.9.14.

24. E. S. Kawasaki. 1990. Amplification of RNA. In PCR Protocols: A Guide to Methods and Applications. M. A. Innis, D. H. Gelfand, J. J. Sninsky, and T. J. White, editors. Academic Press, San Diego. pp. 21-28.

25. Peterson, B. T., J. A. Brooks, and A. G. Zack. 1982. Use of microwave oven for determination of postmortem water volume of lungs. J. Appl. Physiol. 52:1661-1663.

26. Roy, L., H. R. Knapp, R. M. Robertson, and G. A. Fitzgerald. 1985. Endogenous biosynthesis of prostacyclin during cardiac catherization and angiography in man. Circulation. 71:434-440.

27. Canonico, A. E., J. T. Conary, B. O. Meyrick, and K. L. Brigham. 1994. Aerosol and intravenous transfection of human $\alpha$-1-antitrypsin gene to lungs of rabbits. Am. J. Respir. Cell Mol. Biol. 10:24-29.

28. K. L. Brigham. 1989. Prostanoids. In Handbook of Inflammation, Vol. 6 Mediators of Inflammatory Process, P. Henson and R. Murphy, editors. Elsevier Science Publishing Co., Inc., New York. pp. 1-14.

29. Christman, B. W., P. L. Lefferts, I. A. Blair, and J. R. Snapper. 1990. Effect of platelet-activating factor receptor antagonism on endotoxin-induced lung dysfunction in awake sheep. Am. Rev. Respir. Dis. 142:1272-1278.

30. Michael, L. H. J. R. Hunt, R. M. Lewis, and M. L. Entman. 1986. Myocardial Ischemia: Platelet and thromboxane concentrations in cardiac lymph and the effects of ibuprofen and prostacyclin. Circulation Res. 59:49-55. 